УДК: 619:614.48

doi: $10.36359 /$ scivp.2019-20-2.27

\title{
ВИКОРИСТАННЯ ТЕСТ-СИСТЕМ RIDASCREEN ДЛЯ ІМУНОФЕРМЕНТНОГО АНАЛІЗУ ЗА ДЕТЕКЦІЇ ЗАЛИШКОВОЇ КІЛЬКОСТІ МЕТАБОЛІТІВ НІТРОФУРАНІВ У М'ЯСНІЙ СИРОВИНІ
}

\author{
А. Л. Старосельська, здобувач ${ }^{5}$, \\ Ж. Є. Кліщова, здобувач
}

Сумський національний аграрний університет, вул. Г. Кондратьєва, 160, м. Суми, 40021, Україна

У статті наведено результати досліджень м'ясної сировини на вміст залишкової кількості метаболітів нітрофуранів. За допомогою тест-систем RIDASCREEN для імуноферментного аналізу встановлено наявність метаболіту фурациліну семікарбозид (SEM) у зразках яловичини, свинини та курятини, метаболіту фуразолідону 3-аміно-2оксазолідінон (AOZ) у зразках курятини та метаболіту фуралтадону - 3-аміно-5морфолінометил-2-оксазолідінон (AMOZ) у зразку свинини. Розробка ефективного і швидкого експрес методу детекиії залишкової кількості метаболітів нітрофуранів є важливим кроком y рамках програми державного моніторингу залишків ветеринарних препаратів та забруднювачів у живих тваринах $i$ необроблених харчових продуктах тваринного походження.

Ключові слова: БЕЗПЕЧНІСТЬ, М'ЯСНА СИРОВИНА, МЕТАБОЛІТИ НІТРОФУРАНІВ, ІМУНОФЕРМЕНТНИЙ АНАЛІЗ, ТЕСТ-СИСТЕМИ.

Харчові продукти - наймасовіший вид продукції, яку споживають люди. Якість і безпечність харчових продуктів - основні чинники, які визначають здоров'я нації та сприяють підвищенню її генофонду. У більшості країн світу діють системи контролю або сертифікації якості та безпечності харчових продуктів. Якість і безпечність харчових продуктів в Україні, особливо останніми роками, викликають серйозне занепокоєння $[1,2]$. Така ситуація стосується особливо ринку м'ясних продуктів. М'ясні вироби - джерело повноцінного білка, однак, крім корисних для організму нутрієнтів, м'ясо та м'ясна продукція можуть бути джерелом великої кількості потенційно небезпечних і токсичних речовин хімічного та біологічного походження. Якісні м'ясні продукти можна виробити лише з якісної сировини, а проблема сировинної бази України є першою з найактуальніших [3].

Одним зі шляхів вирішення проблеми забезпечення населення м'ясом i м'ясопродуктами є прискорення зростання забійної худоби та домашньої птиці. У зв'язку з цим в тваринництві та птахівництві застосовуються різноманітні стимулятори росту, які в декілька разів можуть знижувати вартість м'яса, впливаючи при цьому на показники безпечності та якості продукту [4]. Умисна фальсифікація тваринної сировини пов'язана 3 незаконним використанням біологічних домішок у кормах тварин. Ось чому необхідно швидко розробляти методики, які дозволяють визначати ці речовини в продуктах [5]. На території ЄС нітрофурани заборонені до застосування у ветеринарії з 1994 року. Занепокоєння вчених викликають довгострокові ефекти нітрофуранів, визнаних канцерогенними речовинами. $€$ ризик розвитку онкологічних захворювань у людей, які вживають в їжу продукти, що містять ці препарати. Нітрофурани згубно діють на грампозитивні і грамнегативні мікроорганізми, трихомонади, амеби, еймерії, гістомонади [6-10].

${ }^{5}$ Науковий керівник - Т. І. Фотіна, д-р вет. наук, професор 
В Україні питання обігу антимікробних засобів у тваринництві регулюється Законом «Про ветеринарну медицину» та підзаконними документами, які встановлюють порядки реєстрації ветеринарних препаратів, ліцензування виробництва ветеринарних препаратів, правила продажу ветеринарних препаратів, вимоги до ветеринарних аптек, тощо. До того ж, зараз в Україні діє програма державного моніторингу залишків ветеринарних препаратів та забруднювачів у живих тваринах і необроблених харчових продуктах тваринного походження. План державного моніторингу виконується відповідно до Законів України «Про державний контроль за дотриманням законодавства про харчові продукти, корми, побічні продукти тваринного походження, здоров'я та благополуччя тварин», «Про основні принципи та вимоги до безпечності та якості харчових продуктів», «Про ветеринарну медицину», у тому числі Директиви СС 96/23/ СС, з метою отримання загального уявлення про стан справ щодо дотримання законодавства про харчові продукти тваринного походження в Україні, вимог Європейського союзу та інших країн світу [7].

Враховуючи вищенаведене, метою нашого дослідження було встановлення безпечності м'яса та м'ясної продукції за вмістом нітрофуранів.

Матеріали i методи. Дослідження проводили на кафедрі ветсанекспертизи, мікробіології, зоогігієни та безпеки і якості продуктів тваринництва Сумського НАУ. Проби м'яса відбирали згідно з ГОСТ Р 51447-99 «Мясо и мясные продукты. Методы отбора проб». Для проведення досліджень всього була відібрана 31 проба: 9 зразків телятини, 8 зразків свинини, 7 зразків курятини та 7 зразків індички. Кількісне визначення метаболітів фурациліну (CEM), фуразолідону (АО3) та фуралтадону (АМО3) проводили методом імуноферментного аналізу з використанням тест-систем RIDASCREEN «Нітрофурани» та імуноаналізатора (табл. 1). Даний метод є конкурентним імуноферментним аналізом, адже лунки стрипів мікротитрувальних планшеток вкриті специфічними антитілами, що зв'язуються з антитілами до метаболіту, який необхідно визначити. А вільні метаболіти зразка і кон’югат досліджуваного метаболіту конкурують за центри зв’язку антитіл.

Табличя 1

Технічна характеристика набору використовуваних тест-систем

\begin{tabular}{|c|c|c|c|c|}
\hline № & Назва тест-системи & $\begin{array}{l}\text { Межа виявлення } \\
\text { (м'ясо, птиця, } \\
\text { печінка) }\end{array}$ & $\begin{array}{c}\text { Перехресна } \\
\text { чутливість, } \\
\text { \% } \\
\end{array}$ & Здатність витягу, \% \\
\hline 1 & $\begin{array}{l}\text { Набір для визначення нітрофуранів } \\
\text { SEM RIDASCREEN } ® \text { Nitrofuran } \\
\text { (SEM) }\end{array}$ & 300 нг/кг & $\begin{array}{c}\text { АMO3 }<0.01 \\
\text { АО } 3<0.01 \\
\text { АГД }<0.01\end{array}$ & $\begin{array}{c}\text { свинина, яловичина }-92-94 \\
\text { курятина, індичка }-110\end{array}$ \\
\hline 2 & $\begin{array}{l}\text { Набір для визначення нітрофуранів } \\
\text { AOZ, RIDASCREEN, }\end{array}$ & 100 нг/кг & $\begin{array}{l}\text { АMO3 }<0,01 \\
\text { АГД }<0,01 \\
\mathrm{CEM}<0,01\end{array}$ & $\begin{array}{l}\text { птиця, свинина, яловичина } \\
-80-100\end{array}$ \\
\hline 3 & $\begin{array}{l}\text { Набір для визначення нітрофуранів } \\
\text { AMOZ, RIDASCREEN, }\end{array}$ & 200 нг/кГ & $\begin{array}{l}\text { АМО3 }<0,05 \\
\text { АГД }<0,05\end{array}$ & $\begin{array}{c}\text { яловичина, печінка }-70-90 \\
\text { свинина }-70-80 \\
\text { птиця }-70-100\end{array}$ \\
\hline
\end{tabular}

Процедура тестування. Пробопідготовка включала етапи гомогенізації, приватизації, екстрагування, центрифугування, концентрації та знежирювання. Спочатку гомогенізували пробу (100 г) у гомогенізаторі; 3 г гомогенату змішували з 3 мл дистильованої води і додавали 6 мл етилацетату, після чого пробірку інтенсивно струшували по осі "вгору-вниз" 10 хв. Далі центрифугували при кімнатній температурі (20-25 $\left.{ }^{\circ} \mathrm{C}\right)$ протягом 10-ти хвилин при 3000 об. 4 мл ефірного екстракту (що відповідало 2 г проби) переносили в нову чисту пробірку і випаровували екстракт при $60^{\circ} \mathrm{C}$ у слабкому струмі азоту; сухий залишок розчиняли в 1 мл суміші ізооктану з хлороформом (2/3) і ретельно перемішували на вортексі; додавали до розчину 0,5 мл буфера i продовжували перемішування протягом однієї хвилини. 
Центрифугували при кімнатній температурі $\left(20-25^{\circ} \mathrm{C}\right)$ протягом 10 -ти хвилин при 3000 об. Для аналізу використовували 50 мкл розчину з верхнього шару на 1 лунку планшета. Лунки планшета попередньо маркували. Вносили по 50 мкл стандартних і досліджуваних розчинів до відповідних пар лунок. Додавали по 50 мкл розведеного розчину кон'югату на дно кожної лунки, після чого в лунки вносили по 50 мкл готового розчину антитіл. Обережно перемішували, інкубували протягом двох годин при кімнатній температурі $\left(20-25{ }^{\circ} \mathrm{C}\right)$. Промивали лунки дистильованою водою 2 рази. У кожну лунку додавали по 50 мкл субстрату i по 50 мкл хромогену, перемішували й інкубували при кімнатній температурі $\left(20-25{ }^{\circ} \mathrm{C}\right)$ протягом 30 хвилин у темряві.

Для припинення реакції вносили 100 мкл стоп-розчину до кожної лунки та миттєво перемішували шляхом струшування планшета вручну. Протягом 60-ти хвилин після додавання стоп-реагенту вимірювали оптичну щільність у кожній лунці, використовуючи

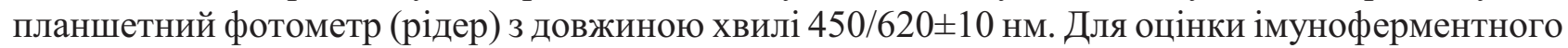
аналізу RIDASCREEN використовували спеціальне програмне забезпечення RIDA "SOFT Win" (арт. № Z9999).

Результати й обговорення. Визначення нітрофуранів у м'ясі та м'ясних продуктах базується на виявленні їх метаболітів. Оскільки у тваринництві найбільш часто використовуються такі препарати нітрофуранового ряду, як фурацилін, фуразолідон та фуралтадон, їх детекцію проводили методом визначення відповідних метаболітів:

Фурацилін - метаболіт семікарбозид (SEM).

Фуразолідон - метаболіт 3-аміно-2-оксазолідінон (AOZ).

Фуралтадон - метаболіт 3-аміно-5-морфолінометил-2-оксазолідінон (AMOZ) [8].

Результати проведеного імуноферментного аналізу на визначення залишків нітрофуранів у зразках м'ясної сировини, наведені у табл. 2.

Таблиия 2

Вміст метаболітів нітрофуранів у м'ясній сировині

\begin{tabular}{|c|c|c|c|c|c|c|}
\hline № & $\begin{array}{c}\text { Вид м’ясної } \\
\text { сировини }\end{array}$ & $\begin{array}{l}\text { Кількість } \\
\text { проб, } \mathrm{n}\end{array}$ & $\begin{array}{l}\text { МДР за } \\
\text { НТД }\end{array}$ & $\begin{array}{l}\text { Вміст метаболіту } \\
\text { SEM }\end{array}$ & $\begin{array}{c}\text { Вміст метаболіту } \\
\text { AOZ }\end{array}$ & Вміст метаболіту AMOZ \\
\hline 1 & Яловичина & 9 & не $\geq 0,01$ & $\begin{array}{c}\text { виявлено } \\
(\geq 0,01 \text { од/г), } \mathrm{n}=1\end{array}$ & $\begin{array}{c}\text { не виявлено } \\
(\leq 0,01 \text { од/г), n=9 }\end{array}$ & $\begin{array}{c}\text { не виявлено }(\leq 0,01 \text { од/г), } \\
\mathrm{n}=9\end{array}$ \\
\hline 2 & Свинина & 8 & не $\geq 0,01$ & $\begin{array}{c}\text { виявлено } \\
(\geq 0,01 \text { од/г), } \mathrm{n}=1\end{array}$ & $\begin{array}{c}\text { не виявлено } \\
(\leq 0,01 \text { од/г), n=8 }\end{array}$ & $\begin{array}{c}\text { виявлено }(\geq 0,01 \text { од/г), } \\
\mathrm{n}=1\end{array}$ \\
\hline 3 & Курятина & 7 & не $\geq 0,01$ & $\begin{array}{c}\text { виявлено } \\
(\geq 0,01 \text { од/г), } \mathrm{n}=3 \\
\end{array}$ & $\begin{array}{c}\text { виявлено }(\geq 0,01 \\
\text { од/г), } \mathrm{n}=2 \\
\end{array}$ & $\begin{array}{c}\text { не виявлено }(\leq 0,01 \text { од/г), } \\
\mathrm{n}=7\end{array}$ \\
\hline 4 & Індичка & 7 & не $\geq 0,01$ & $\begin{array}{c}\text { не виявлено } \\
(\leq 0,01 \text { од/г), n=7 }\end{array}$ & $\begin{array}{c}\text { не виявлено } \\
(\leq 0,01 \text { од/г), n=7 }\end{array}$ & $\begin{array}{c}\text { не виявлено }(\leq 0,01 \text { од/г), } \\
\mathrm{n}=7\end{array}$ \\
\hline
\end{tabular}

У результаті проведених досліджень нам вдалось встановити, що найбільш контамінованим видом м'ясної сировини є курятина: у трьох зразках із семи було виявлено вміст метаболіту SEM (фурацилін) та у двох зразках встановлено вміст метаболіту $A O Z$ (фуразолідон), у кількостях, що перевищують МДР. В одному із 8 зразків свинини було виявлено вміст метаболітів SEM (фурацилін), а в іншому AMOZ (фуралтадон). Стосовно яловичини, то лише в одному з 9 зразків було встановлено вміст метаболіту SEM (фурацилін) у кількості, що перевищує МДР. Жодної проби індички, контамінованої залишками препаратів нітрофуранів у кількостях, що перевищують МДР не було виявлено. 


\title{
В И С Н О В К И
}

Виходячи 3 даних проведених досліджень, можна констатувати, що проблема забруднення м'ясних продуктів антимікробними препаратами, зокрема нітрофуранами, $\epsilon$ актуальною. Тому постає необхідність розробки ефективних і швидких методів детекції залишкової кількості даних препаратів у м'ясній сировині. Застосування тест-систем RIDASCREEN для імуноферментного аналізу дає змогу швидко отримати дані про вміст метаболітів нітрофуранів у досліджуваних зразках харчових продуктів; час, затрачений на проведення тесту складає лише 1 год 15 хв.

Перспективи досліджень. Апробувати використання тест-систем RIDASCREEN для імуноферментного аналізу при визначенні залишкової кількості нітрофуранів у готовій м'ясній продукції.

\section{USE OF RIDASCREEN TEST SYSTEMS FOR ELISA DURING DETECTION OF RESIDUAL QUANTITIESNITROFURANE METABOLITES IN MEAT RAW MATERIALS}

\author{
A. L. Staroselskaya, J. E. Klischova \\ Sumy National Agrarian University \\ 160, G. Kondratieva, Sumy, 40021, Ukraine
}

S U M M A R Y

The article presents the results of studies of raw meat on the content of the residual amount of nitrofuran metabolites. Since in the livestock sector the most frequently used drugs of the nitrofuran series are furatsilin, furazolidone and furaltadone. The listed drugs are synthetic antibiotics, which have proven to be antiprotozoal and antifungal drugs. The effectiveness of these drugs depends on the concentration and type of pathogen, but the use of nitrofurans is limited due to the peculiarities of their metabolism, which is currently not well understood.

Using the RIDASCREEN test systems for ELISA, the presence of the metabolite furatsilina semicarboside (SEM) in samples of beef, pork and chicken, the metabolite of furazolidone 3-amino2-oxazolidinone (AOZ) in samples of chicken and furaltadone-metabolite-metabolite-metolitolmetabolite 3-amino-oxolidone (AOZ) in samples of chicken and furaltadone-metabolitol-metabolitemetolitol 3 morpholinomethyl-2-oxazolidinone (AMOZ) in a pork sample. The development of an effective and rapid express method for detecting the residual amount of nitrofuran metabolites is an important step in the program of state monitoring of residues of veterinary drugs and pollutants in live animals and unprocessed foods of animal origin.

Since meat products are a source of complete protein, in addition to nutrients useful for the body, meat and meat products can be a source of large amounts of potentially dangerous and toxic substances of chemical and biological origin. This is the need to develop rapid methods for the diagnosis of residues that reduce the cost of meat, while affecting the safety and quality indicators of the product.

Keywords: SAFETY, MEAT RAW MATERIALS, NITROFURANE METABOLITES, IMMUNO-ENZY ANALYSIS, TEST SYSTEM. 


\title{
ИСПОЛЬЗОВАНИЕ ТЕСТ-СИСТЕМ RIDASCREЕN ДЛЯ ИММУНОФЕРМЕНТНОГО АНАЛИЗА ПРИ ДЕТЕКЦИИ ОСТАТОЧНЫХ КОЛИЧЕСТВМЕТАБОЛИТОВ НИТРОФУРАНОВ В МЯСНОМ СЫРЬЕ
}

\author{
А. Л. Старосельская, Ж. Е. Клищева \\ Сумской национальный аграрный университет, \\ ул. Г. Кондратьева, 160, г. Сумы, 40021, Украина
}

А Н Н О А ЦИ Я

В статье приведены результаты исследований мясного сырья на содержание остаточного количества метаболитов нитрофуранов. С помощью тест-систем RIDASCREEN для иммуноферментного анализа установлено наличие метаболита фурацилина семикарбозид (SEM) в образцах говядины, свинины и курятины, метаболита фуразолидона 3-амино-2оксазолидиноны (AOZ) в образцах курятины и фуралтадона - метаболит 3-амино-5 морфолинометил-2-оксазолидинон (AMOZ) в образце свинины. Разработка эффективного и быстрого экспресс метода детекции остаточного количества метаболитов нитрофуранов является важным шагом в рамках программы государственного мониторинга остатков ветеринарных препаратов и загрязнителей в живых животных и необработанных пищевых продуктах животного происхождения.

Ключевые слова: БЕЗОПАСНОСТЬ, МЯСНОЕ СЫРЬЕ, МЕТАБОЛИТЫ НИТРОФУРАНОВ, ИММУНОФЕРМЕНТНЫЙ АНАЛИЗ, ТЕСТ-СИСТЕМЫ.

\section{Л I T E P A T У P A}

1. Смоляр В. І. Харчова експертиза / В. І. Смоляр - К.: Здоров'я, 2005. - 448 с.

2. Баль-Прилипко Л. В. Актуальні проблеми галузі / Л. В. Баль-Прилипко - К.: Міністерство аграрної політики України, 2010 - 374 с.

3. Анализ современного состояния проблемы использования антибиотиков в качестве кормовой добавки / Н. В. Черкашина [и др.] // Аграрный вестник Урала. - 2011.- № 3 (82). C. 39-43.

4. Моніторинг залишків протимікробних препаратів у продукції тваринництва різних виробників та основні причини забруднення / А. М. Головко, Н. Г. Пінчук, Г. В. Дмитриєва, Т. Ф. Кисельова // Ветеринарна медицина України. - 2014. Вип. 5 (219) - С. 28-30.

5. Чем заменить на практике запрещенные ветеринарные препараты? / Толкач Н. // Белорусское сельское хазяйство.- 2016. - № 3. - С 167.

6. Держпродспоживслужба розробляє внутрішній план заходів боротьби зі стійкістю до антибіотиків. [Електронний ресурс] - Режим доступу: http://www.consumer.gov.ua/News/4849/Derzhprodspozhivsluzhba_rozroblyae_vnutrishniy_plan zakhodiv_borotbi_zi_stiykistyu_do_antibiotikiv

7. Vass M., Nitrofuran antibiotics: a review on the application, prohibition and residual analysis/ Vass M., Hruska K., Franek M // Veterinarni Medicina.- 2008. - Vol. 53 (9). P. 469-500.

8. Проблема резистентности (устойчивости) к антибиотикам [Электронный ресурс] Режим доступа http://biofile.ru/bio/4271.html

9. Wegener H. C. Danish initiatives to improve the safety of meat products / H. C. Wegener // Meat Science - 2009. - 9 p.

10. Brown E. Antibiotic cycling orrotation, a systematic review of the evidence of efficacy / E. Brown, D. Nathwanc // J. Antimicrob. Chemother. - 2005. - Vol. 55(1). - C. 6-9. 


\section{References}

1 Smoliar V. I. Kharchova ekspertyza. / V. I. Smoliar - K.: Zdorovia, 2005. - 448 s. (in Ukrainian)

2 Bal-Prylypko L.V. Aktualni problemy haluzi / L.V. Bal-Prylypko - K.: Ministerstvo ahrarnoi polityky Ukrainy, 2010 - 374 s. (in Ukrainian)

3 Analyz sovremennoho sostoianyia problemы yspolzovanyia antybyotykov $\mathrm{v}$ kachestve kormovoi dobavky / N. V. Cherkashyna [y dr.] // Ahrarnyi vestnyk Urala. - 2011.- №3 (82). - S. 3943. (in Russian)

4 Monitorynh zalyshkiv protymikrobnykh preparativ u produktsii tvarynnytstva riznykh vyrobnykiv ta osnovni prychyny zabrudnennia / A. M. Holovko, N. H. Pinchuk, H. V. Dmytryieva, T. F. Kyselova // Veterynarna medytsyna Ukrainy. - 2014. Vyp. 5 (219) - S. 28-30. (in Ukrainian).

5 Chem zamenyt na praktyke zapreshchennye veterynarnye preparaty? / Tolkach N. // Belorusskoe selskoe khaziaistvo.- 2016 - № 3 - S 167. (in Belarus)

6 Derzhprodspozhyv sluzhba rozrobliaie vnutrishnii plan zakhodiv borotby zi stiikistiu do antybiotykiv. [Elektronnyi resurs] http://www.consumer.gov.ua/News/4849/Derzhprodspozhivsluzhba_rozroblyae_vnutrishniy_plan zakhodiv borotbi_zi_stiykistyu do antibiotikiv

7 Vass M., Nitrofuran antibiotics: a review on the application, prohibition and residual analysis / Vass M., Hruska K., Franek M // Veterinarni Medicina.- 2008. - Vol. 53 (9). P. 469-500.

8 Problema rezystentnosty (ustoichyvosty) k antybyotykam [Elektronnyi resurs] - Rezhym dostupa:http://biofile.ru/bio/4271.

9 Wegener H. C. Danish initiatives to improve the safety of meat products / H. C. Wegener // Meat Science - 2009. - 9 p.

10. Brown E. Antibiotic cycling orrotation, a systematic review of the evidence of efficacy / E. Brown, D. Nathwanc // J. Antimicrob. Chemother. - 2005. - Vol. 55(1). - C. 6-9.

Рецензент - Г. А. Зон, к. вет. н., професор, СНАУ. 